\title{
The Optimization of Silk Fabric Production Process
}

\author{
Asif Shahriar* \\ Testing Engineer, Textile Division, Modern Testing Services, Bangladesh
}

Received 01 April 2019, Accepted 03 June 2019, Available online 05 June 2019, Vol.9, No.3 (May/June 2019)

\begin{abstract}
Our sericulture sector is so degraded that today we are not concerned to this sector. So in order to know the condition of sericulture, production process flow chart, annual production, comparison about production of our country and other neighbouring countries a theses is important from where we also able to know about local production condition, elaboration of several terms and definitions related to silk as well as the problems which are related to the degradation of sericulture sector. The ways of minimizing production loss is also elaborated in these. Most of the experiment and data are collected from Bangladesh sericulture Research \& Training Institute, Rajshahi as well as Sopura Silk Mills Ltd. Rajshahi and rest of them are collected from journal, book and internet. The conventional system prior to this is to understand the root level of sericulture of Bangladesh. The outcome of the theses is that it helps us to understand why our sericulture sector is so lack behind. It enriches our concern about silk production and by this way our annual production will be increased and sericulture will be a profitable sector.
\end{abstract}

Keywords: Silk Fabric etc.

\section{Introduction}

Sericulture is identified as a prospective earning sector in Bangladesh. It is capable of creating employment as well as alleviating poverty for major portion of the population in the country especially in rural areas. Bangladesh has huge prospect for developing this sector with proper aids and necessary supports of Government and non-Government organizations. But because of various socio-economic reasons it is not considered as an established sector and the survivability of it becoming questionable. Certainly now this industry is highly struggling to survive. There are some factors like access to finance, infrastructure, inconsistencies government policy and bureaucracy, environmental factors, multiple taxes and levies, access to modern technology, unfair competition, marketing problems and non-availability of raw materials locally etc. are making this industry pitiable. So there is need of conducting a study on sericulture industry to measure the effectiveness of it and to understand the level of progress in concerned areas.

We have a great possibilities to be gain at this sector, but due to some reason this sector is lag behind. To improve this sector concern is essential to the both known and unknown persons about sericulture. For this reason continuous research of the researcher frequent seminar for the manufacturer as well as concerned people and sufficient training for the unknown people is essential to improve this sector.

\section{Methodology}

\section{Place of Research}

The whole study is done at Bangladesh Sericulture Research Training Institute, Rajshahi and necessary data are collected from Sopura Silk Mills ltd, Rajshahi. The sericulture research center is a perfect place for continuing a theses because necessary equipment are available here, the officers a staffs of that institute are very friendly to give necessary data and show the usage of the machines and equipment. Besides the staffs of Sopura Silk Mills Ltd., an established silk cloth manufacturers are very helpful to give necessary information in spite of their business of manufacturing.

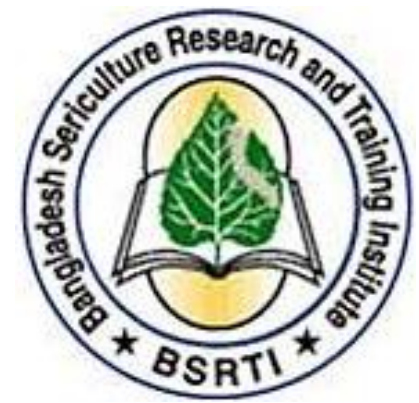

Fig 1.1: Logo of Bangladesh Sericulture Research 


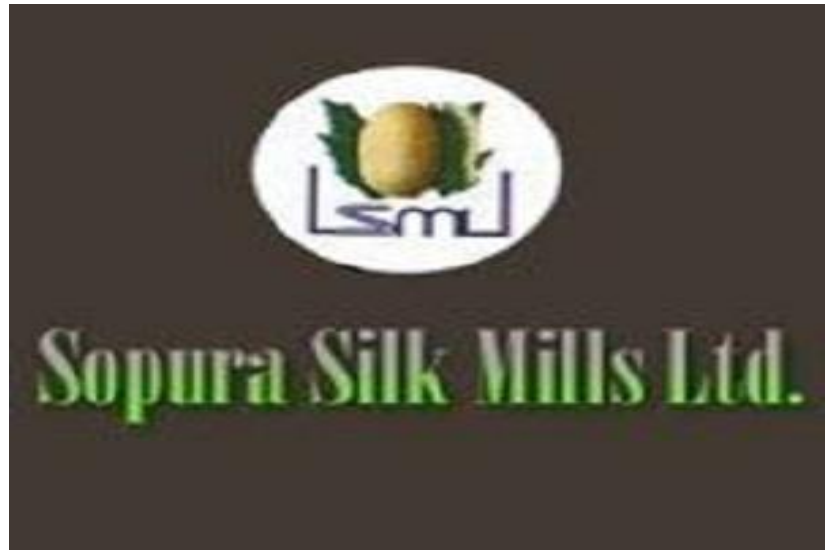

Fig 1.2: Logo of Sopura Silk mills Ltd, Rajshahi and Training Institute (BSRTI)

\section{Global information}

\section{Graphical Representation: Chemical composition of} silk fiber

In order to understand the each element $\%$ of a silk fibre a graphical view is very helpful. The below are the table (Table 1).

Table 1: Chemical composition of silk fiber

\begin{tabular}{|c|c|}
\hline Element of silk fiber & Amount $\%$ \\
\hline Fibroin & 75 \\
\hline Ash of silk fibroin & 0.5 \\
\hline Sericin & 22.5 \\
\hline Fat \& Wax & 1.5 \\
\hline Mineral Salt & 0.5 \\
\hline Total & 100 \\
\hline
\end{tabular}

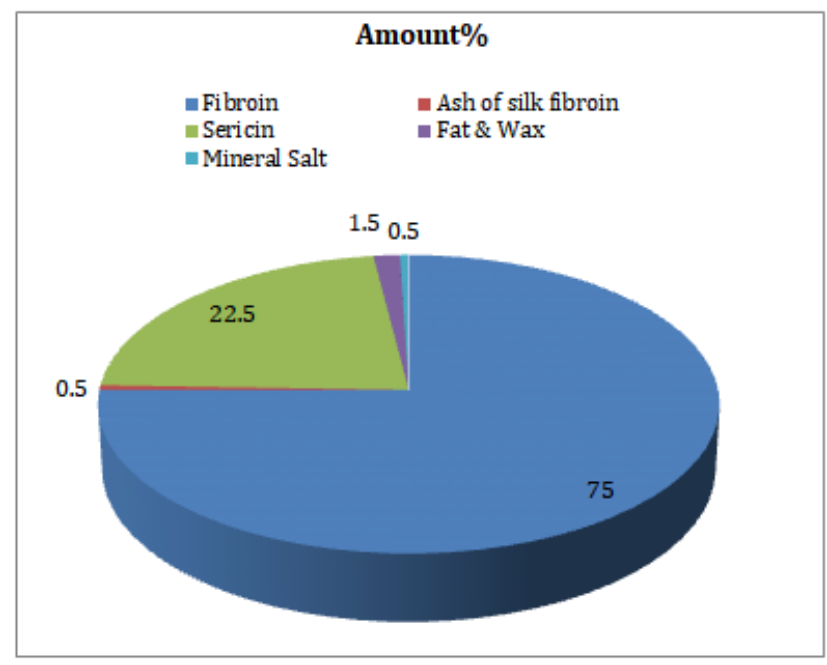

Chemical Composition of Silk Fiber

\section{About silk filament}

A cocoon cell is composed of a continuous protein filament which is called "bave". According to variation of race the length of bave varies from 300-1600 meter. There are two parts of the bave or filament. The core is called fibrin and the surface sticky covering is called sericin. Fibrin is divided into two parts each single part of which is called "brin".a bave is formed with fibrin covered by sticky sericin during coming out of filament of larva from its glands of mouth.

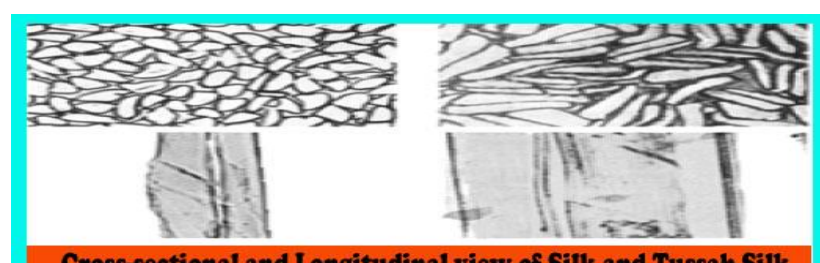

Cross-sectional and Longitudinal view of Silk and Tussah Silk

\section{Cross-sectional and longitudinal view of silk fiber}

X- ray of silk:_X- ray photographs show definite $\mathrm{x}$-ray spots, which indicate that fibroin is crystalline in structure. The crystal is very much more than the outer visible surface of the of the fibre
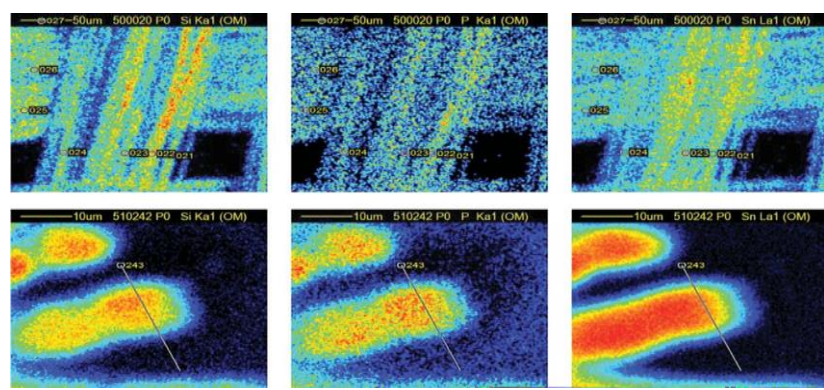

$\mathrm{X}$ ray of silk fiber and silk cocoon

Comparison of silk production of Bangladesh with other countries

Table 2: Production of raw Mulberry silk during past ten years (Metric ton)

\begin{tabular}{|c|c|c|c|}
\hline Year & India & Bangladesh & Nepal \\
\hline $2005-06$ & 15445 & NA & 1.4 \\
\hline $2006-07$ & 16525 & NA & 4.1 \\
\hline $2007-08$ & 16245 & NA & 4.31 \\
\hline $2008-09$ & 15610 & NA & 1.36 \\
\hline $2009-10$ & 16322 & 40 & 1.19 \\
\hline $2010-11$ & 16360 & 38 & 1.09 \\
\hline $2011-12$ & 18272 & 42 & 1.31 \\
\hline $2012-13$ & 18715 & 43 & 1.57 \\
\hline $2013-14$ & 19476 & 44 & 1.76 \\
\hline
\end{tabular}

Silk production in Bangladesh during 2009-2014

Table 3: Silk production in Bangladesh during 2009 2014

\begin{tabular}{|c|c|c|}
\hline Fiscal year & $\begin{array}{c}\text { Cocoon } \\
\text { Production(MT) }\end{array}$ & $\begin{array}{c}\text { Raw Silk } \\
\text { Production(MT) }\end{array}$ \\
\hline $2009-10$ & 400.00 & 40.00 \\
\hline $2010-11$ & 390.00 & 38.00 \\
\hline $2011-12$ & 430.00 & 42.50 \\
\hline $2012-13$ & 430.00 & 43.00 \\
\hline $2013-14$ & 448.00 & 44.50 \\
\hline Average & 418.00 & 41.60 \\
\hline
\end{tabular}




\section{Flow Chart of Silk fabric production}

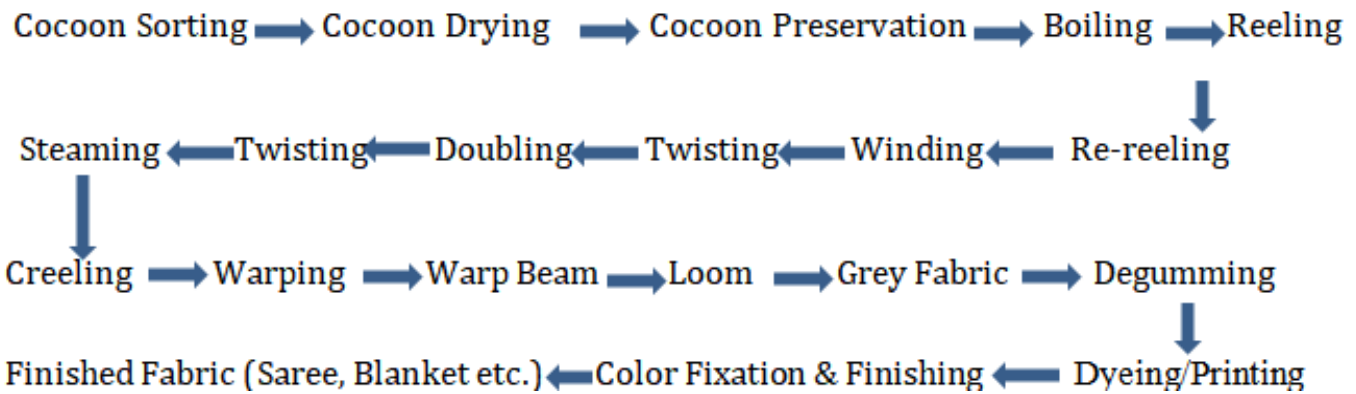

\section{Cocoon Sorting}

Percentage of faultless cocoons and various types of faulty cocoons (Studied on the egg supplied by Bangladesh Sericulture Research Development Board and Bangladesh Sericulture Research and Training Institute separately, cultivated at two different places):

Table 4: Percentage of faultless cocoons and various types of faulty cocoons (Nistary cocoons)

\begin{tabular}{|c|c|c|}
\hline \multicolumn{2}{|c|}{ Nistary Cocoons (Desi cocoons) } \\
\hline & $\begin{array}{c}\text { Chandraghona } \\
\text { (Egg supplied by } \\
\text { BSRDB) }\end{array}$ & $\begin{array}{c}\text { Bholahat } \\
\text { (Egg supplied by } \\
\text { BSRTI) }\end{array}$ \\
\hline $\begin{array}{c}\text { Total cocoons } \\
\text { observed }\end{array}$ & 100 & 100 \\
\hline Spotted cocoons & 3 & 6 \\
\hline Hairy cocoons & 4 & 0 \\
\hline Double cocoons & 1 & 0 \\
\hline Thin cocoons & 0 & 2 \\
\hline Bend cocoons & 0 & 0 \\
\hline Pierced cocoons & 5 & 3 \\
\hline Total Faulty & 13 & 89 \\
\hline Cocoons & 87 & \\
\hline
\end{tabular}

Table 5: Percentage of faultless cocoons and various types of faulty cocoons (Developed cocoons)

\begin{tabular}{|c|c|c|}
\hline \multicolumn{2}{|c|}{ Developed Cocoons (Crossed cocoons) } \\
\hline $\begin{array}{c}\text { Chandraghona } \\
\text { (Egg supplied by } \\
\text { BSRDB) }\end{array}$ & $\begin{array}{c}\text { Bholahat } \\
\text { (Egg supplied by } \\
\text { BSRTI) }\end{array}$ \\
\hline $\begin{array}{c}\text { Total cocoons } \\
\text { observed }\end{array}$ & 100 & 100 \\
\hline Spotted cocoons & 3 & 1 \\
\hline Hairy cocoons & 1 & 1 \\
\hline Double cocoons & 0 & 0 \\
\hline Thin cocoons & 1 & 1 \\
\hline Bend cocoons & 0 & 0 \\
\hline Pierced cocoons & 2 & 1 \\
\hline Total Faulty & 7 & 4 \\
\hline Cocoons & 93 & 96 \\
\hline Faultless cocoons & & \\
\hline
\end{tabular}

\section{Cocoon Drying}

The main aim of drying is to kill the pupa as well as drying the dead cocoons. The temperature should be $90-100^{\circ} \mathrm{C}$ and to kill the pupa $20-25 \mathrm{~min}$ is required. After that sometime is required to dry the dead cocoon .If the temperature exceeds rather than requirement, the sericine become cemented which will create problems at the time of reeling. Moisture of raw cocoons is more than that of dried cocoon. It varies from element to element which is shown in the following table:

Table 6: Moisture of the elements of silk cocoon both raw and dry condition

\begin{tabular}{|c|c|c|}
\hline Cocoon & Raw Silk Cocoon & Dry silk Cocoon \\
\hline Cocoon cell & $11-12$ & $6-7$ \\
\hline Pupa & $75-79$ & $7-13$ \\
\hline Silk cocoon & $61-64$ & $6-12$ \\
\hline
\end{tabular}

\section{Subsequent steps of cocoon drying}

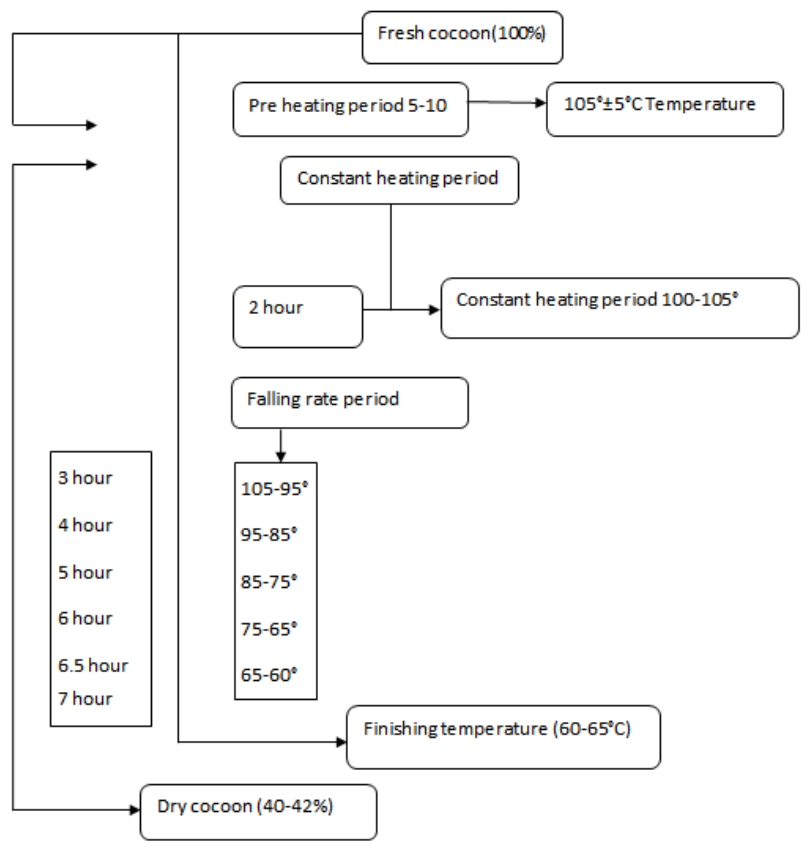

\section{The conditions of drying cocoon}

- At initial stage the surface temperature of cocoon should be remain $105^{\circ} \pm 5^{\circ} \mathrm{C}$

- If the temperature exceeds the maximum level, sericin become degenerate rapidly, as a result the ends of the cocoons become difficult to find out.

- Due to the degeneration of sericin, the production of raw silk become decreased.

- So at the time of drying temperature should be controlled strictly. 
- In case of steam heating, temp. should be remained at $102^{\circ} \pm 2^{\circ} \mathrm{C}$

- If temperature is excess, then the cocoons will not be dried equally.

- The finishing temperature should be lessened at $55^{\circ} \mathrm{C}$ as a result of which the sericin cannot be degenerated. As a result, the reeling efficiency remain constant and the production of silk become higher.

Drying of silk cocoon is a major problem. Farmers normally dry it on sun. Although this method is easy and time consuming, but it decreases the strength of the yarn of the dried cocoon. Because the ultra -violet ray of sun react with the amino group of silk and finally the quality of silk cocoon become damaged. As a result, at the time of reeling, yarn become cut frequently and the reliability \% of cocoon is decreased. On the other hand, in rainy season sufficient sunlight is not available. As a result it is difficult to dry the cocoon in rainy season.

The following temperature profile is essential to use in case of multi-fuel cocoon drier:

\section{$105^{\circ} \mathrm{C} \pm 5^{\circ} \mathrm{C}-1$ Hour \\ $100^{\circ} \mathrm{C}-105^{\circ} \mathrm{C}-1.50$ Hour \\ $85^{\circ} \mathrm{C}-95^{\circ} \mathrm{C}-1.50$ Hour \\ $75^{\circ} \mathrm{C}-85^{\circ} \mathrm{C}-1$ Hour \\ $60^{\circ} \mathrm{C}-65^{\circ} \mathrm{C}-30$ Minute}

\section{Comparison of various types of dryers}

\section{Comparison between sundry and drying with black cloth}

A comparison between mere sun drying and sun drying covering black fabric are as follows:

Drying of Silk Cocoon:

Table 7: Drying Of Silk Cocoon

\begin{tabular}{|c|c|c|}
\hline Items & Sun Dry & $\begin{array}{c}\text { Drying covering black } \\
\text { cloth }\end{array}$ \\
\hline $\begin{array}{c}\text { Raw silk } \\
\text { Recovering \% }\end{array}$ & 54.9 & 60.2 \\
\hline Reliability\% & 75.3 & 85.8 \\
\hline Silk wastage\% & 28.5 & 17.4 \\
\hline Elongation\% & 17.5 & 22.7 \\
\hline
\end{tabular}

Comparative statement of various types of driers about time needed and cost/kg

Table 8: Comparative statement of various types of driers

\begin{tabular}{|c|c|c|}
\hline $\begin{array}{c}\text { Medium of drying } \\
\text { cocoon }\end{array}$ & $\begin{array}{c}\text { Time needed to } \\
\text { dry cocoon }\end{array}$ & Cost/kg \\
\hline sunlight & $\begin{array}{c}7-8 \text { Days }(168-192 \\
\text { hours) }\end{array}$ & - \\
\hline $\begin{array}{c}\text { Multi-fuel cocoon } \\
\text { drier }\end{array}$ & $4-5$ Hours & $0.60-0.80$ \\
\hline Other driers & $6.5-7$ Hours & $1.0-1.25$ \\
\hline
\end{tabular}

\section{Cocoon Preservation}

To preserve the cocoons protective trays is essential where ant, fly other insect can not be entered. The four legs of the drier can be drown into bowl full of water, this allow not to reach any ant like insect to damage the cocoons. The door and windows of the room should be opened so that air come into the house and dry the cocoons. It also helps to keep the moisture of the cocoons.

- $\quad$ Only the selected and dry cocoons have to keep inside the room.

- Here the temperature should be from $25-30^{\circ} \mathrm{C}$ and R.H.\% from $65 \%-70 \%$

- Various types of silk wastes and the cocoons unable for reeling should keep away from the room.

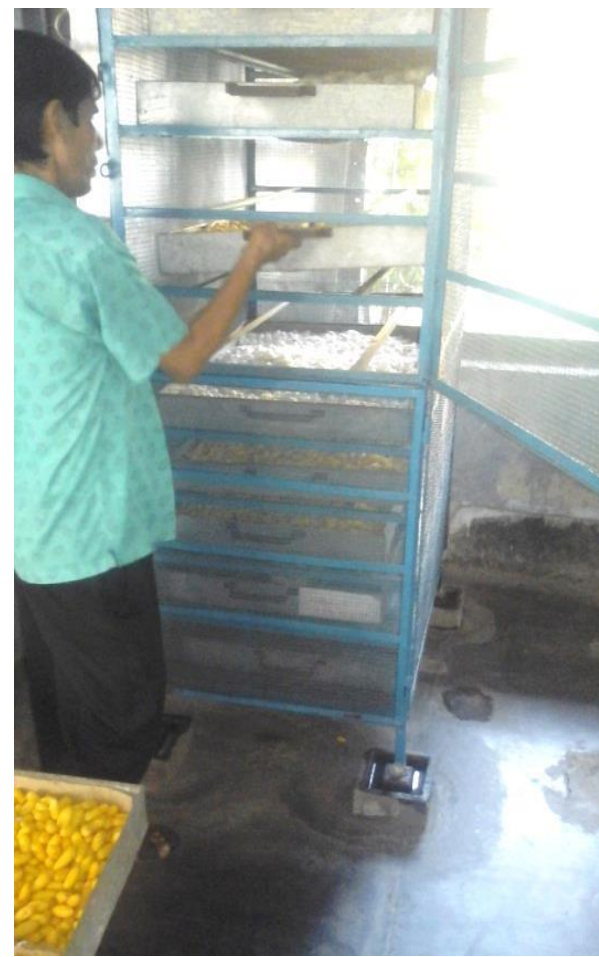

Cocoon Preserving Rack

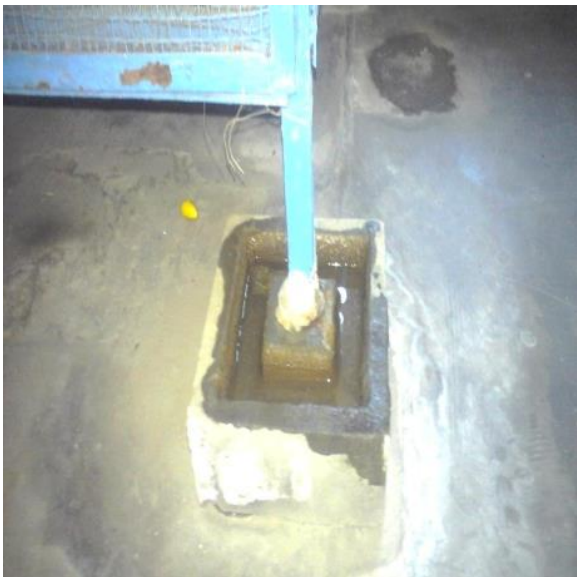

Water bath to resist insets 


\section{Reeling}

\section{Calculations of number of silk cocoons required} during reeling

Suppose,

Weight of silk filament of a single cocoon is $\mathrm{W}=0.09$ gm.

System weight, $\mathrm{w}=1 \mathrm{~kg}$

System length, $\mathrm{l}=1 \mathrm{~m}$

Length of silk filament of a single cocoon is $\mathrm{L}=255 \mathrm{~m}$

So, from the formula of direct system, we know,

Denier $=\frac{l \times W}{L \times w}$

Denier $=\frac{9000 \mathrm{~m} \times 0.09 \mathrm{~g}}{255 \mathrm{~m} \times 1 \mathrm{~g}}=3.17$ Denier

Standard silk yarn Denier $=22$

No. of silk filament required at the time of reeling $=22 / 3.17$

$=6.94$

$\approx 7$

\section{Another example}

Suppose,

Weight of silk filament of a single cocoon is $\mathrm{W}=0.085$ gm.

System weight, $\mathrm{w}=1 \mathrm{~kg}$

System length, $\mathrm{l}=1 \mathrm{~m}$

Length of silk filament of a single cocoon is $\mathrm{L}=310 \mathrm{~m}$

So, from the formula of direct system, we know,

Denier $=\frac{l \times W}{L \times w}$

Denier $=\frac{9000 \mathrm{~m} \times 0.04 h}{315.5 \mathrm{~g} \times 1 \mathrm{~g}}=2.46$ Denier.

Standard silk yarn Denier $=22$

No. of silk filament required at the time of reeling $=22$ /

2.46

$=8.9$

$\approx 9$

Length, weight and denier of filament of 10 sample of Mullbery (chaita)
Table 9: Length, weight and denier of filament of 10 sample of Mullbery(chaita)

\begin{tabular}{|c|c|c|c|}
\hline Serial No. & Length(m) & Weight(g) & (Denier) \\
\hline 1 & 290 & 0.07 & 2.17 \\
\hline 2 & 445 & 0.10 & 2.02 \\
\hline 3 & 345 & 0.09 & 2.34 \\
\hline 4 & 475 & 0.12 & 2.27 \\
\hline 5 & 380 & 0.12 & 2.84 \\
\hline 6 & 410 & 0.12 & 2.63 \\
\hline 7 & 300 & 0.10 & 3.0 \\
\hline 8 & 370 & 0.12 & 2.91 \\
\hline 9 & 300 & 0.09 & 2.7 \\
\hline 10 & 400 & 0.09 & 2.02 \\
\hline Mean & 371.5 & 0.102 & 2.49 \\
\hline
\end{tabular}

On the other hand, Indian multi volatine races contain 300-400 meter. Indian multi volatine hybrids 400-550 meter. Newly evolved hybrids 600-800 meters. Uni/ Bi-Volatine hybrids1000-1500 meter.

Reeling is an essential step to manufacture silk yarn. Filament is unwound by this step onto an Aluminium frame.

\section{Dyeing}

The raw fabric is hard and harsh because sericin is present inside it. This sericin is removed by washing with soap and soda. As a result, the fabric become white and soft. Next the fabric is washed and treated with acetic acid. Last of all, the fabric is squeezed and finally it becomes alkali free and neutral. The follow dyes are mostly used for silk dying:

\section{Acid Dye \\ 2. Reactive Dye \\ 3. Napthol dye}

In case of solid dyeing, Acid dye is commonly used. In case of tie dye or buttique, napthol or reactive dye is used. Acid color is also suitable for printing.

\section{Printing}

The colors and methods employed are the same as for wool, except that in the case of silk no preparation of the material is required before printing, and ordinary dry steaming is preferable to damp steaming. Both acid and basic dyes play an important role in silk printing, which for the most part is confined to the production of articles for fashion goods, handkerchiefs, and scarves, all articles for which bright colors are in demand. Alizarine and other mordant colors are mainly used for any goods that have to resist repeated washings or prolonged exposure to light. In this case the silk frequently must be prepared in alizarine oil, after which it is treated in all respects like cotton, namely steamed, washed and soaped, the colors used being the same. Silk is especially adapted to discharge and reserve effects. Most of the acid dyes can be discharged in the same way as when they are dyed on wool. Reserved effects are produced by printing mechanical 
resists, such as waxes and fats, on the cloth and then dyeing it in cold dye-liquor. The great affinity of the silk fiber for basic and acid dyestuffs enables it to extract coloring matter from cold solutions and permanently combine with it to form an insoluble lake. After dyeing, the reserve prints are washed, first in cold water to remove any color not fixed onto the fiber, and then in hot water or benzene to dissolve out the resisting bodies.

Recipe of printing paste

- $\quad$ Fine gum paste : $1 \mathrm{Kg}$

- Reactive color : $100 \mathrm{~g}$

- $\mathrm{NaCl}: 10 \mathrm{~g}$

- $\operatorname{Soda}\left(\mathrm{CaCO}_{3}\right): 10 \mathrm{~g}$

- Hot water: 1 Litre.

Procedure

- At first 0.75 litre of hot water, is taken into $1 \mathrm{~kg}$ gum paste and stared.

- After that reactive color, $\mathrm{NaCl}$ and $\mathrm{CaCO}_{3}$ are taken on the above amount and frequently stared.

- Rest of the 1 Liter of water is poured after certain time while staring. Last of all, the paste become prepared.

\section{Color Fixation \& Finishing}

\section{Color Fixation}

For acid, color steaming is continued for 30-60 minutes and then the color become fixed. If there is no steaming chamber, steaming is continued in cottage steamer for 3-3.5 hours. In case of pigment printing, curing is done with high temperature to fix color.

\section{Finishing}

To improve the surface appearance and luster the following finishes are applied.

- Screw finishing: in every liter 1-3 gram mercerized soap or oil emulsion is applied and treated 15-20 minute. After that 2-4 milligram formic or lactic or acetic acid is applied and treated 15-20 minute.

- Screw Finishing (soft): Serenine SG of 10-20 gram/Liter and acetic acid 1 mili liter/ liter is applied.

- Soft Handling: Sericine HCS of 10 gram /liter and sandoluble NV/Ratifix of 10 gram /litre is applied. $\mathrm{pH}$ is maintained at 5.0-5.5 using acetic acid.

- Finishing removing water-spot: Cerol of 20-40 gram /liter and cerenine HCS of 10-20 gram /liter is applied. $\mathrm{pH}$ is maintained at 5.0-5.5 using acetic acid.

\section{Finished Fabric}

Last of all we get our expected final product .Normally silk saree is very popular not only Bangladesh but foreign countries. Besides, Blanket, scarf etc are also Popular.

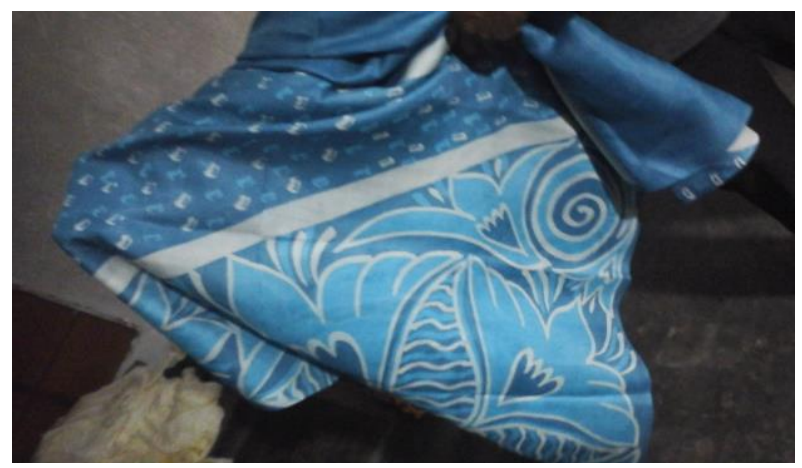

A Silk Saree

\section{Discussion and Result}

\section{Discussion}

\section{Comments from Table no. 2}

1. As india is a large country and the so the production of raw silk is very higher than any other countries of SAARC. Their production level becoming higher day after day. Because of proper research sericulture sector is becoming a profitable sector in India.

2. The production level of mulberry silk in Bangladesh was at negligible in the years 2005-2009.From 2009 to 2014 it is in a rising position although it is very less than that of India but more than that of Nepal.

3. The production level of mulberry silk in Nepal is less than that of Bangladesh. But of course they are at rising position.

\section{Comments from table no. 3}

1. In the year 20009-10, 2010-2011, cocoons production level is 400 to 390 Metric ton respectively. It means the production level of cocoons become slightly low.

2 . In the year $2010-11,2011-12$, cocoons production level remain constant that is 430 metric ton.

3 . In the year 2013-14, the cocoons production level is 418 metric ton, the highest than that of other years from 2009-14.It means that sericulture sector in Bangladesh now is a rising position.

\section{Comments from figure no.2}

1. In the year 20009-10, 2010-2011, raw silk production level is 40 to 38 Metric ton respectively. It means the production level of cocoons become slightly low.

2. In the year 2010-11, 2011-12, raw silk production level more or less remain constant that is $42.5-43$ metric ton respectively. 
3. In the year 2013-14, the raw silk production level is 44.5 metric ton, the highest than that of other years from 2009-14.It means that sericulture sector in Bangladesh now is a rising position.

\section{Comments from table no 4 and 5}

1) Number of total faulty cocoons of Bholahat are less than that of Chandraghona in both case (Nistary and developed cocoons) and vice versa.

2) In both case, faultless cocoons are more, egg supplied by BSRTI than BSRDB.

3) The number of faults for developed cocoons or crossed cocoons are less than Nistary or desi cocoons.

\section{Comments from table no 6}

1. In cocoon cell, both for raw or dry silk moisture level is the least than that of other two part of the silk cocoon.

2. After drying, both the moisture of the pupa and silk cocoons are reduced.

3. In case of pupa, after drying, moisture become $79 \%$ to $13 \%$, which is a evolutionary change in moisture.

4. In case of silk cocoons, after drying, moisture become $64 \%$ to $12 \%$, which is also a evolutionary change in moisture.

\section{Comments from table no 7}

1.All the positive agents such as raw silk recovering\%, Reliability\%, elongation $\%$ are more in case of drying cocoons covering black cloth than that of mere sun drying.

2. Wastage $\%$ is more at mere sundrying than that of drying cocoons covering black cloth.

3. So, it is clear that drying cocoons covering black cloth is preferable to mere sun drying process.

\section{Comments from table no: 8}

1. In case of sun light time needs maximum 192 hours to dry cocoons.

2. In case of multi- fuel cocoon dryer and other dryer's maximum time need 5 hours and 7 hours respectively.

3. Multi- fuel cocoon dryer is the best as the least time is required to dry cocoons than other dryers or sun light.

\section{Comments from table no: 9}

1. In case of sun light there is no cost but time required is very long 192 hours.

2. In case of Multi-fuel Dryer, cost $/ \mathrm{kg}$ is $0.6-0.8$ taka and time required is 4-5 hours.

3 . In case of other dryers, cost/kg is $1-1.25$ taka and time required is 6.5 - 7 hours.

4. So, multi- fuel dryer is the best dryer to dry cocoons at minimum time and the least cost is required.
5. So, multi-fuel drier is the best drier and popular drier for maximum circumstances.

\section{Thesis Outcome}

The summary of the Thesis outcome is as follows:

1. The number of fault of developed or crossed cocoons are less than that of Nistary or desi cocoons so developed cocoons or crossed cocoons are preferable to nistary cocoons.

2. To reach to the goal of both quality as well as production, a manufacturer should emphasize on the previous record of the cocoon quality and the place where the eggs are hatched. As silk fabric is an aristocratic fabric, he should draw attention to the quality rather than price. Thus both quality of the final product will be maintained and the production will be more satisfactory than that of low quality cocoons.

3. In a raw cocoon, majority percentage of moisture remain in pupa and after drying the moisture percentage is reduced exponentially.

4. It is clear that drying cocoons covering black cloth is preferable to mere sun drying process as different parameters are maintained well at the first process.

5. Multi- fuel cocoon dryer is the best as the least time is required to dry cocoons than other dryers or sun light.

6. Multi- fuel cocoon dryer is the best as the least time is required to dry cocoons than other dryers or sun light.

7. Multi-fuel drier is the best drier and popular drier for maximum circumstances as minimum time and the least cost is required and different types of fuel can be used depending on the supply of fuel or stock of fuel.

8. The less the denier of filament, the more number of filament is required to maintain a definite denier of a yarn and vice versa. The initial portion and the final portion of the filament of a cocoon are thinner than that of the middle portion.so at initial and final portion more filament $\mathrm{s}$ are casted during reeling to maintain a definite denier.

9. The average denier of a single filament is more or less 2-3 Denier.

10. Sericulture sector in Bangladesh now is a rising position.

11. The annual production of Bangladesh is very less than that of India. What is the reason of this? From root level, it is observed that both wastage and production loss is negligible. So, the major cause of less production is that the maximum length of filament per cocoon of Bangladesh (500 meter) is very lesser than that of India (1500 meter). Maximum1000 meter less per cocoon decreases the total production of Bangladesh. So research is indispensable to increase the length per cocoon to increase total production.

\section{Conclusion}

The study revealed the phenomenon that the better the cocoon the better the production as well as quality. The 
environment is very important as without proper environment all attempt would failure. Specially the preservation of the dried cocoon is important as various insects can damage the cocoons. Also the temperature and R.H\% should be maintained well. During production less wear and tear should be ensured as less friction less wastage and more production. The utmost use of the wastage reduces production cost. Skilled worker should be employed and worker should be trained to be skilled. People should be shown the benefits of sericulture. Finally, research is necessary to be continued to produce more crossed races of our native silk races. By this way, length of filament per cocoon will be increased and gradually total production as well as annual production will be increased. Thus we can be able to achieve our goal and keep our aristocratic and luxurious sericulture sector in the competitive world.

\section{References}

http://article.sapub.org/10.5923.j.economics.20140403.02.h tml\#Sec1

http://textilefashionstudy.com/chemical-composition-ofsilk-fiber-silk-natural-fiber/

https://2.bp.blogspot.com/QNVaC8MYuAg/VZf6c_ar7il/AAAAAAAACbA/iNJ1Ad_GanU /s1600/Silk-fibre.jpg

https://www.researchgate.net/profile/Paul Garside2/publication/232834950/figure/fig5/AS:304521 231257627@1449614927735/fig-2-Elemental-protoninduced-X-ray-PIXE-maps-for dynamite-tin-weighted-dT1silk.png
Sericulture Manual 3-Silk Reeling, FAO Agricultural Service Bulletin 15/3,Rome,Page 12-16, 1972.

http://www.google.com/m?q=production+of+mulberry+silk +past+ten+years+of+bd.\&client=ms-opera-miniandroid\&channel=new

http://www.google.com/m?q=production+of+mulberry+silk +past+ten+years+of+bd.\&client=ms-opera-miniandroid\&channel=new

Reeling \& Weaving Manual, Bangladesh Sericulture Board, Ministry of textiles \& Jute, Page 19 First Edition, May 2007 [ Author : Kamal Mostafa].

Reeling \& Weaving Manual, Bangladesh Sericulture Board, Ministry of textiles \& Jute, Page 19 First Edition, May 2007 [ Author : Kamal Mostafa ].

Reeling \& Weaving Manual, Bangladesh Sericulture Board, Ministry of textiles \& Jute, Page 20 First Edition, May 2007 [ Author : Kamal Mostafa].

www.indiaagronet.com/ indiaagronet/sericulture/contents/Cocoon\%20quality.ht $\mathrm{m}$

http://www.wormspit.com/degumming.htm https://en.wikipedia.org/wiki/Textile_printing http://www.rose-plastic.us/872.1.html http://www.rose-plastic.us/872.1.htm

Reeling \& Weaving Manual, Bangladesh Sericulture Board, Ministry of textiles \& Jute, Page 45 First Edition, May 2007 [ Author : Kamal Mostafa ].

Reeling \& Weaving Manual, Bangladesh Sericulture Board, Ministry of textiles \& Jute, Page 46 First Edition, May 2007 [ Author : Kamal Mostafa ].

Reeling \& Weaving Manual, Bangladesh Sericulture Board, Ministry of textiles \& Jute, Page 31 First Edition, May 2007 [ Author : Kamal Mostafa ]. 